\title{
Physiological Relationships of Rapidly Growing Mycobacteria
}

\author{
Adansonian Classification \\ By J. CERBÓN AND L. F. BOJALIL \\ Unidad de Patología, Escuela de Medicina, UNAM, Hospital General, \\ Mexico 7, D.F., México
}

(Received 24, August 1960)

\section{SUMMARY}

The physiological properties of a collection of rapidly growing acid-fast bacilli were analysed according to a simple mathematical method proposed by Sneath. Closer relationships were observed between Mycobacterium smegmatis and $M$. phlei than between either of them and $\boldsymbol{M}$. fortuitum; all three species form natural groups. On the basis of the Adansonian classification two other small groups were found which probably are new species. Some unnamed strains which could not be included in any of the groups mentioned above were placed in the classification and collectively labelled irregular branch. A key for the rapid identification of the specific groups is described.

\section{INTRODUCTION}

The characterization and taxonomic position of mycobacteria have been a constant problem, with numerous proposals for an adequate classification taking into account different view-points. Cultural and physiological properties, cytochemical tests, pathogenicity and antigenic relationships have been considered by many authors (Frey \& Hagan, 1931; Pinner, 1932; Thompson, 1932; Gordon, 1937; Gordon \& Hagan, 1938; Uesaka, 1956; Parlett \& Youmans, 1956, 1958; Kushner, McMillen \& Senderi, 1957; Shepard, 1957; McMillen \& Kushner, 1959; Vogel, 1959; Wayne, 1959; Bönicke, 1958, 1960).

Three well-characterized species are recognized among the rapidly growing acidfast bacilli: Mycobacterium smegmatis (Trevisan), Lehmann \& Neumann, M. phlei Lehmann \& Neumann and $M$. fortuitum Cruz. Gordon \& Smith $(1953,1955)$ reclassified into these three species many others which previously had been given other names. The present study aims at an analysis of the physiological properties and relationships of a number of strains whose gross and microscopic characters make them seem similar to established species of rapidly growing mycobacteria, as well as the determination of their taxonomic position by the method proposed by Sneath $(1957 a, b)$ which has given good results in similar studies (Hill, 1959; Bojalil \& Cerbón, to be published).

\section{METHODS}

The strains studied are listed in Table 1. They were maintained in LöwensteinJensen medium (Wheeler, 1951) and checked for viability and purity by microscopic examination and subcultures in different media. Single cell cultures of the strains were used to test their physiological properties: 


\section{Table 1. Strains of Mycobacterium studied}

\begin{tabular}{|c|c|c|}
\hline No. in tables & Name & Source and number \\
\hline $\mathbf{1}$ & M. smegmatis & Rutgers University, S. A. Waksman \\
\hline $\mathbf{2}$ & Mycobacterium sp. & UPHG, A-57-439 lymph node \\
\hline 3 & M. phlei st. & Tuberkulose Forschung Institute, Börstel, Bönicke, 169 \\
\hline 4) & M. ranae & National Trudeau Bank, W. Steenken Jr, Trudeau Labs. \\
\hline 5 & M. lacticola & $\begin{array}{l}\text { Escuela Nacional de Agricultura, Chapingo, México, } \\
\text { Etchegaray }\end{array}$ \\
\hline 6 & M. ranae 110 & National Trudeau Bank, W. Steenken Jr., Trudeau Labs. \\
\hline$\gamma$ & Mycobacterium sp. & 607, Rutgers University, S. A. Waksman \\
\hline 8 & M. friedmanii & ATCC 114 \\
\hline 9 & Mycobacterium sp. & 599 Rutgers University, S. A. Waksman \\
\hline 10 & Mycobacterium sp. & ATCC 65 \\
\hline 11 & Mycobacterium sp. & $\begin{array}{l}\text { Soil, Escuela Nacional de Agricultura, Chapingo, México } \\
\text { Etchegaray }\end{array}$ \\
\hline 12 & Mycobacterium sp. & 362, ATCC, received as $M$. butyricum \\
\hline 13 & M. stercoris & ATCC, 281 \\
\hline 14 & Mycobacterium sp. & UPHG, sputum,* C-912 \\
\hline 15 & Mycobacterium sp. & UPHG, sputum, C-153 \\
\hline 16 & Mycobacterium sp. & UPHG, peritoneum, $*$ A-57-429-1 \\
\hline 17 & Mycobacterium sp. & $\begin{array}{l}\text { Facultad de Medicina de El Salvador, Alfonso Trejos, } \\
\text { subcutaneous abscess }\end{array}$ \\
\hline 18 & Mycobacterium sp. & UPHG, lung cavity, A-59-52-1* \\
\hline 19 & Mycobacterium sp. & UPHG, lung cavity, B-57-1787* \\
\hline 20 & M. phlei & $\begin{array}{l}\text { Strains NTB and W, Trudeau Labs., W. Steenken Jr. } \\
\text { and Rutgers University, S. A. Waksman }\end{array}$ \\
\hline 21 & Mycobacterium sp. & UPHG, lung, B-59-637* \\
\hline 22 & Mycobacterium sp. & UPHG, bronchial aspiration, H.I. 4955 \\
\hline 23 & Mycobacterium sp. & UPHG, spinal fluid, H.I. 5987 \\
\hline 24 & Mycobacterium sp. & UPHG, sputum, C-227* \\
\hline 25 & Mycobacterium sp. & UPHG, sputum 1450 \\
\hline 26 & Mycobacterium sp. & UPHG, R.D. 25 sputum \\
\hline 27 & M. butyricum & ATCC 357 \\
\hline 28 & Mycobacterium sp. & UPHG, RD.47 ${ }^{\wedge}$ sputum \\
\hline 29 & M. fortuitum & ATCC, 6841 , Cruz original isolate, McMillen \\
\hline 30 & M. fortuitum & $\begin{array}{l}\text { Malta strain, from E. Agius. NCTC, 8573. Medical Re- } \\
\text { search Council Unit, Oxford, England }\end{array}$ \\
\hline 31 & M. fortuitum & M. minetti, strain of Penso, R. E. Gordon, R-480 \\
\hline 32 & M. fortuitum & Schumper-sputum, McMillen, 14 \\
\hline 33 & Mycobacterium sp. & UPHG, sputum,* Acapulco-343 \\
\hline 34 & Mycobacterium sp. & UPHG, sputum, Acapulco-103 \\
\hline 35 & Mycobacterium sp. & UPHG, sputum, Acapulco-102 \\
\hline 36 & Mycobacterium sp. & UPHG, sputum Acapulco-465 \\
\hline 37 & Mycobacterium sp. & Cornell University, Knaysi, received as $M$. thamnopheous \\
\hline 38 & Mycobacterium sp. & Communicable Disease Centre, Chamblee Georgia, Kubica \\
\hline 39 & Mycobacterium sp. & Escuela Nacional de Ciencias Biológicas, 58375 \\
\hline 40 & Mycobacterium sp. & Veterans Administration Hospital, 380, E. Runyon \\
\hline 41 & Mycobacterium sp. & Veterans Administration Hospital, 518, E. Runyon \\
\hline 42 & Mycobacterium sp. & Veterans Administration Hospital, 481, E. Runyon \\
\hline 43 & Mycobacterium sp. & Cuba-29, Hepatic abscess, Cuba, Habana, Curbelo \\
\hline
\end{tabular}

Differential properties used: (1) Acid from glucose, galactose, mannose, fructose, lactose, maltose, sucrose, trehalose, melibiose, raffinose, L-arabinose, mannitol, sorbitol, dulcitol, $m$-inositol, erythritol and salicin. (2) Utilization of benzoate, citrate, succinate, tartrate, pyruvate and propionate. (3) Temperatures of growth $28^{\circ}, 37^{\circ}, 45^{\circ}, 52^{\circ}$. (4) Resistance to $60^{\circ}$ for $4 \mathrm{hr}$. 
Gross and microscopic morphology, as well as the degree of acid-fastness, are not taken as differential criteria because of their high variability, even within one strain. The capacity for visible growth in 48-72 hr. in Löwenstein-Jensen medium, and in nutrient glycerinated agar was the basis for considering a strain as a rapid grower.

Acid formation from carbohydrates. The cultures were examined for acid production after 7 and 28 days' incubation at $37^{\circ}$ on inorganic nitrogen agar, a modification of the medium of Ayers, Rupp \& Johnson (1919) as described by Gordon \& Smith (1953). Each carbohydrate was sterilized separately from the basal medium. Bromocresol purple was used as the indicator of acid production.

Utilization of organic acids. Modifications of Koser's citrate agar (Gordon \& Smith, 1955) were made by combining $2 \mathrm{~g}$. of the Na salts of benzoic, citric, succinic, pyruvic, or tartaric acids with saline solution buffered to $\mathrm{pH} 6 \cdot 8$, agar, $1.5 \%(\mathrm{w} / \mathrm{v})$ and phenol red as indicator. The alkaline colour of the indicator after incubation at $37^{\circ}$ demonstrates the utilization of an organic acid as a carbon source.

Temperatures of growth. The cultures were inoculated on Löwenstein-Jensen and in Proskaur-Beck liquid medium (Youmans, 1946) and incubated in water baths at $28^{\circ}, 37^{\circ}, 45^{\circ}$ and $52^{\circ}$ for $2-4$ weeks and examined at intervals for growth.

Resistance to $60^{\circ}$ for $4 \mathrm{hr}$. The cultures were inoculated on Löwenstein-Jensen and Proskauer-Beck media previously heated to $60^{\circ}$ and incubated in a water bath at that temperature for $4 \mathrm{hr}$. They were then cooled under running water and incubated at $37^{\circ}$ for 2-4 weeks and examined for growth.

The method developed for the Adansonian classification, as well as the system for quantitative notation, were as described by Sneath (1957 $b$ ).

\section{RESULTS}

The results obtained from the different tests were tabulated: a strain $\times$ strain $(i \times i)$ table was prepared from the similarity indexes obtained, which were expressed in percentages. Another $(\mathrm{i} \times \mathrm{i})$ table was made by rearranging the strains in groups; the latter table is shown diagrammatically in Fig. 1. Consequently, a taxonomic tree was designed (Fig. 2), the branches of which may be considered as species. The three species previously characterized by Gordon \& Smith $(1953,1955)$ remained as groups when subjected to Adansonian analysis. The diagram (Fig. 1) shows that Mycobacterium smegmatis and $M$. phlei (branch 1 , groups 1 and 2 ) join together at a higher percentage $S$ level than with $M$. fortuitum (branch 2, group 1 ). This indicates that these two species are more closely related than either is to the third. The distinctness of $M$. phlei is not very apparent in Fig. 1 because few strains were studied; but in Table 2 it is possible to appreciate that such distinctness exists. Intermediate strains joined independently to one or another of the three established species at variable $S$ values. Also, one can observe the existence of two minor groups (branch 2 , groups 2 and 3 ) related more to $M$. fortuitum than to $M$. smegmatis or $M$. phlei.

The branch named irregular is formed by strains that do not seem to be related to any of the other strains studied. 
J. Cerbón and L. F. Bojalit

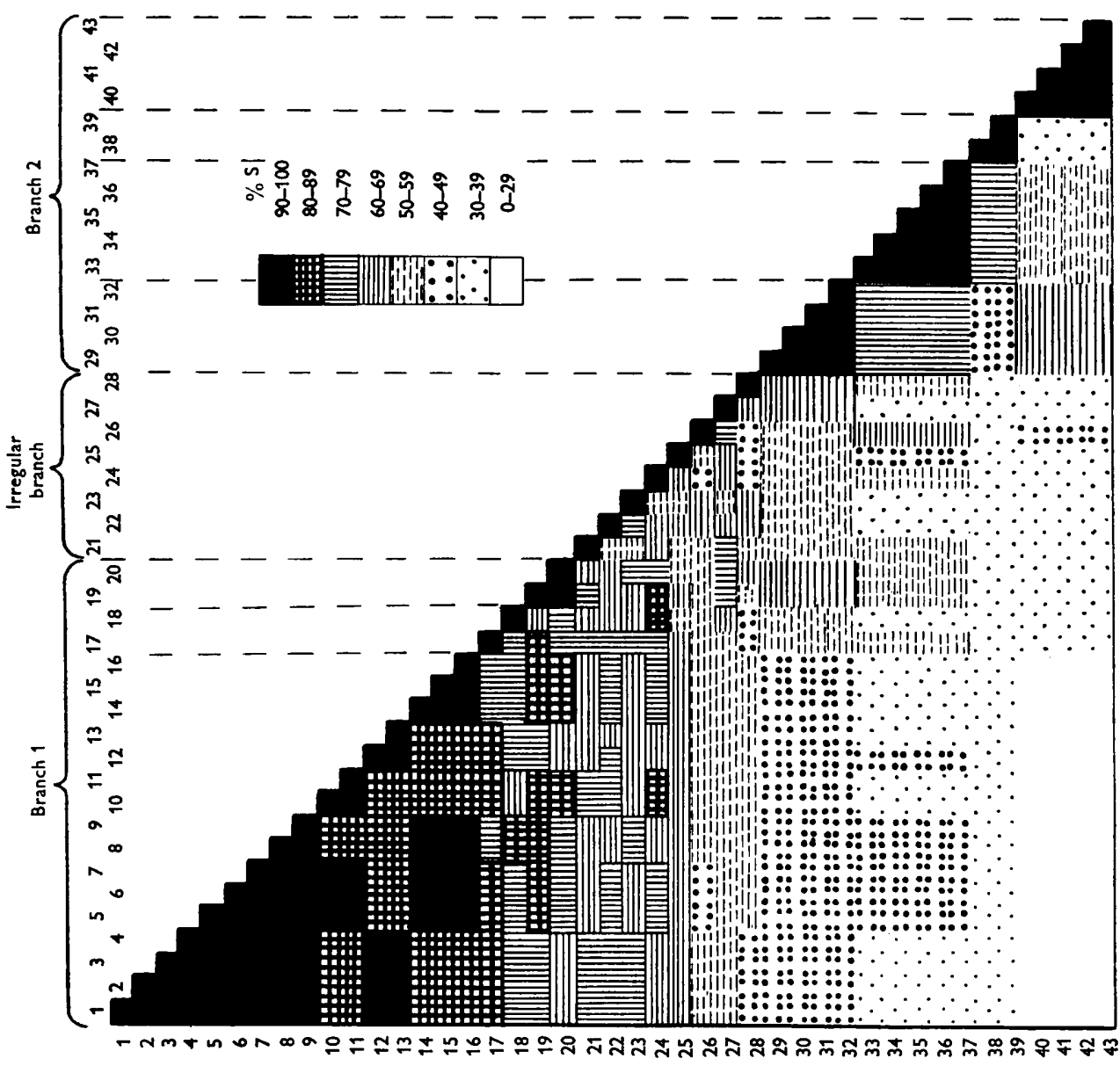

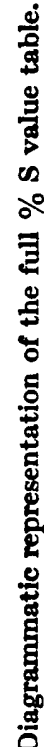

今े

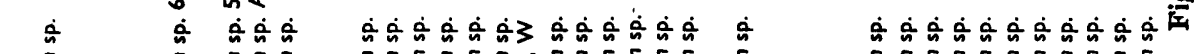

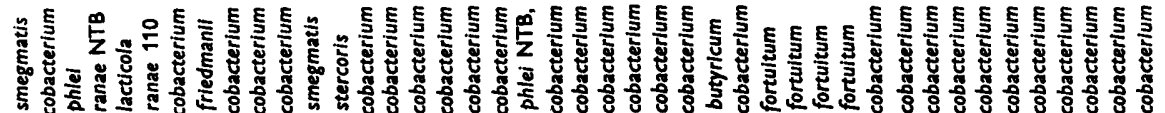

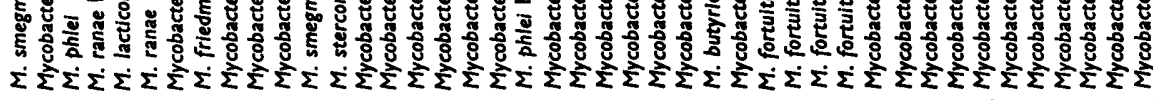

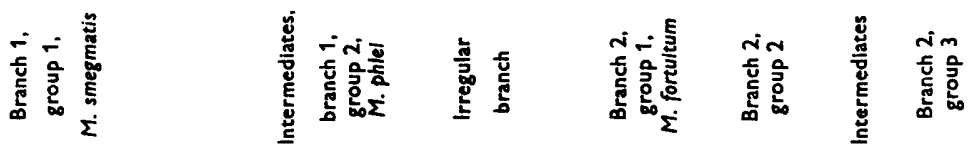




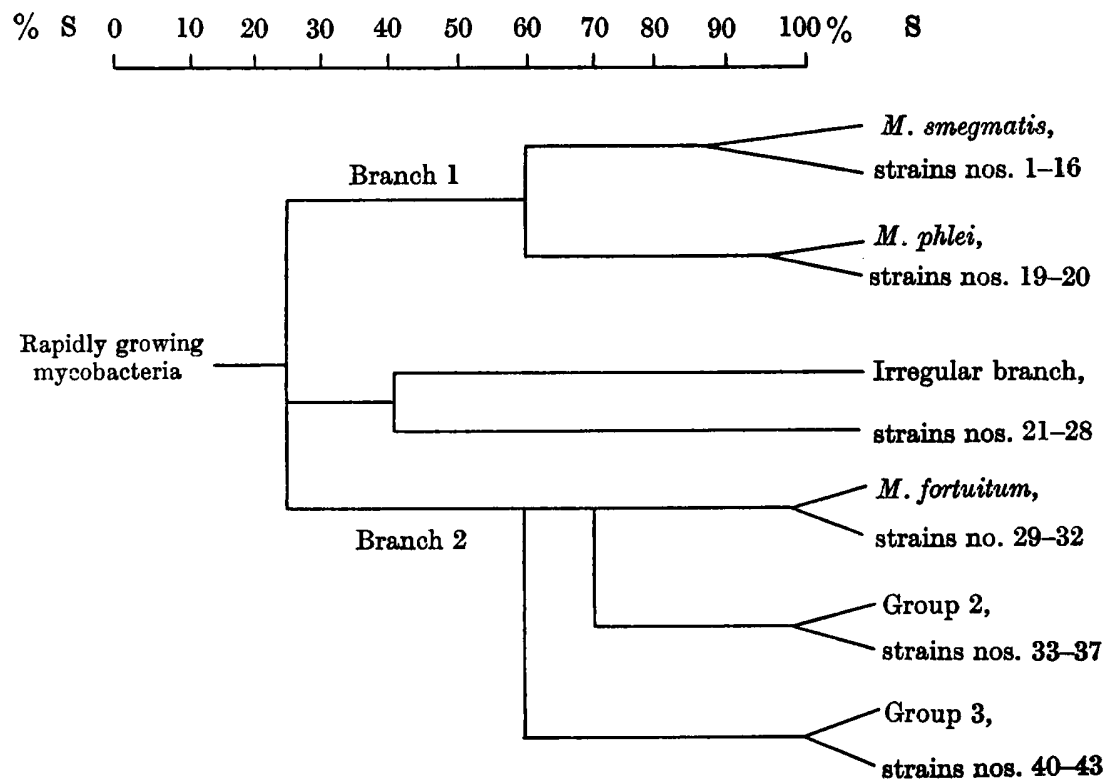

Fig. 2. Taxonomic tree of the rapidly growing mycobacteria. In another paper (Bojalil $\&$ Cerbon, to be published) the group 3 from branch 2 was named group $2 b$. The existence of a new group(group 2, branch 2) more closely related to $M$. fortuitum made necessary the above-mentioned change.

\section{DISCUSSION}

The three species Mycobacterium smegmatis, $M$. phlei and $M$. fortuitum constitute natural groups and can be accepted as logically classified. The Adansonian classification, on the other hand, clearly indicates that $M$. smegmatis and $M$. phlei are much more closely related to each other than they are to $M$. fortuitum.

Branch number 1 is formed by micro-organisms which in general are non-parasitic, capable of utilizing a great variety of carbohydrates. This group of micro-organisms was mostly isolated from soil, plants or animals, and includes Mycobacterium smegmatis and $M$. phlei.

Branch number 2 includes micro-organisms potentially parasitic, capable of utilizing only a limited number of carbohydrates, which were isolated mostly from pathological material or associated with these processes; Mycobacterium fortuitum belongs to this branch, as well as groups 2 and 3, which are definitely characterized. These groups 2 and 3 are small and include but a few unnamed strains. According to the Adansonian classification they are to be considered new species, since they show only a loose relation to pre-established rapidly growing species. On the other hand, these strains (groups 2 and 3 ) are grouped at high levels of similarity $(\mathrm{S}=100 \%)$. This is in contrast to many unnamed strains showing great disparity in their characters, which were included in the branch labelled irregular. Tests depending on subjective evaluation were not included. This makes the number of tests presented here seem small, but we believe that the results obtained by this Adansonian analysis are reliable.

However, it is premature to denote groups 2 and $\mathbf{3}$ as new species and a comparative study with other groups of mycobacteria is being made. 
Table 2. General properties of rapidly growing mycobacteria

\begin{tabular}{|c|c|c|c|c|c|c|}
\hline \multirow[b]{2}{*}{ Property } & \multicolumn{3}{|c|}{ Branch 1} & \multicolumn{3}{|c|}{ Branch 2} \\
\hline & $\begin{array}{c}\text { Group 1 } \\
M . \text { smegmatis }\end{array}$ & $\begin{array}{l}\text { Group 2 } \\
M . \text { phlei }\end{array}$ & $\begin{array}{c}\text { Irregular } \\
\text { branch }\end{array}$ & $\begin{array}{c}\text { Group I } \\
M . \text { fortuitum }\end{array}$ & Group 2 & Group 3 \\
\hline $\begin{array}{c}\text { Pigment on } \\
\text { Löwenstein- } \\
\text { Jensen } \\
\text { medium }\end{array}$ & $\begin{array}{c}\text { Pale- } \\
\text { orange }\end{array}$ & Yellow & $\begin{array}{l}\text { Yellow- } \\
\text { orange }\end{array}$ & $\begin{array}{l}\text { Pale- } \\
\text { straw }\end{array}$ & $\begin{array}{c}\text { Brilliant } \\
\text { yellow }\end{array}$ & $\begin{array}{l}\text { Pale- } \\
\text { straw }\end{array}$ \\
\hline \multicolumn{7}{|l|}{ Acid from: } \\
\hline Glucose & + & + & \pm & + & + & + \\
\hline Galactose & + & + & $( \pm)$ & - & - & - \\
\hline L-Arabinose & + & + & $( \pm)$ & - & - & - \\
\hline Xylose & + & + & + & - & - & - \\
\hline Mannitol & + & + & + & $( \pm)$ & + & - \\
\hline Sorbitol & + & + & + & - & + & - \\
\hline Dulcitol & + & - & $(\mp)$ & - & - & - \\
\hline Mannose & + & + & + & + & + & + \\
\hline Rhamnose & + & - & (Ғ) & - & - & - \\
\hline Fructose & + & + & + & + & + & - \\
\hline M-Inositol & + & - & $( \pm)$ & - & - & - \\
\hline Trehalose & + & + & $( \pm)$ & + & + & - \\
\hline Erythritol & + & - & - & - & - & - \\
\hline \multicolumn{7}{|l|}{ Utilization of: } \\
\hline Benzoate & + & $\cdot-$ & $( \pm)$ & - & - & - \\
\hline Citrate & + & + & $( \pm)$ & + & - & - \\
\hline Succinate & + & + & + & + & + & + \\
\hline Pyruvate & + & + & + & + & + & + \\
\hline Propionate & + & + & + & + & + & + \\
\hline \multicolumn{7}{|c|}{ Growth temperatures } \\
\hline $28^{\circ}$ & + & + & + & + & + & + \\
\hline $37^{\circ}$ & + & + & + & + & + & + \\
\hline $45^{\circ}$ & + & + & $(\mp)$ & - & - & - \\
\hline $\mathbf{5 2}^{\circ}$ & - & + & - & - & - & - \\
\hline \multicolumn{7}{|c|}{ Resistance to $60^{\circ}$} \\
\hline $4 \mathrm{hr}$. & - & + & (干) & - & - & - \\
\hline
\end{tabular}

,+ Positive; - , negative; $( \pm)$ the majority gave positive results; $(\mp)$ the majority gave negative results.

In the irregular branch, each strain could represent a specific group by itself. However, until there is particular interest in any of them they should be simply designated Mycobacterium sp., vigorously or poorly fermentative, thus indicating to which of the branches they are more closely related.

The following key (Fig. 3) may serve for the identification of the different groups. One frequently observes some variability in pigmentation and rate of growth in Löwenstein-Jensen medium on primary isolation; however, these properties (pigmentation and rate of growth) can be used for a preliminary identification in subcultures.

The characters listed in the key mentioned above (Fig. 3), are the most constant for each group. If a strain is aberrant in some of its properties, it may be classified incorrectly if the key alone is used; however, the same strain could be classified according to the properties listed in Table 2. 
Studies of Gordon and her colleagues (1937, 1938, 1953, and 1955 principally) on acid-fast bacilli of relatively rapid growth at $28^{\circ}$ and $37^{\circ}$ in ordinary culture media, have allowed the separation of these micro-organisms into three main groups, especially on the basis of temperature relationships and carbohydrate utilization.

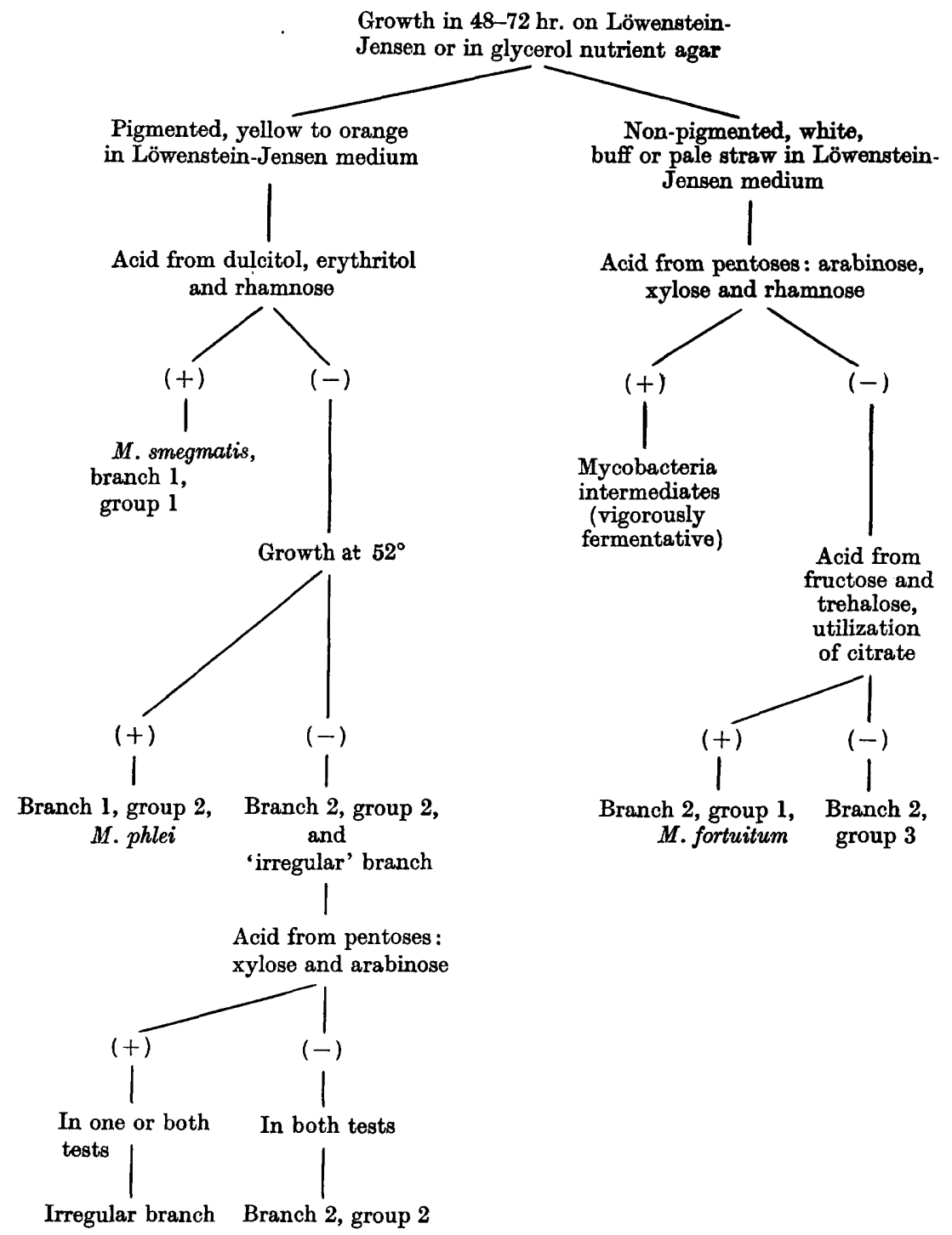

Fig. 3. Schema for the identification of rapidly growing mycobacteria.

The species Mycobacterium smegmatis, $M$. phlei and $M$. fortuitum are the only ones well characterized (up to the time of the latest reports). The following species, previously described as different, have been considered synonyms of one of these three species; Mycobacterium berolinense Bergey et al., $M$. butyricum Bergey et al., (Korn) Chester, M. friedmanii Holland, M. graminis Chester, M. lacticola Lehmann \& 
Neumann, $M$. ranae (Küster) Bergey et al., $M$. stercoris Bergey et al., and $M$. aquae Maië were considered as synonyms of $M$. smegmatis.

Mycobacterium giae Darzins and M. minettii Penso et al. were listed in the synonyms of $M$. fortuitum.

Groups 2 and 3 of the branch have been compared not only to those species mentioned above, but also to other species such as Mycobacterium balnei, M.marinum, $M$. thamnopheous, and $\boldsymbol{M}$. kansasi and non-photochromogenic and scotochromogenic groups which will be referred to in separate reports. It should be noted, however, that group no. 3 of branch 2 differs markedly from the other studied organisms by its limited capacity to utilize sugars. This character is shown also by non-photochromogenic and photochromogenic micro-organisms. The latter, however, grow slowly, produce pigment and utilize different types of sugars (Bojalil, 1959; Bojalil y Cerbón, 1960). In particular photochromogenic Mycobacteria (including $\boldsymbol{M}$. marinum and $\boldsymbol{M}$. balnei) are capable of using fructose and occasionally galactose; but on the other hand, the non-photochromogenics do not utilize mannose.

Mycobacterium rhodochrous (Gordon, 1957) is not included in this study, it shows very weak acid-fastness and true filamentation and ramification in microcultures, features uncommon in the strains discussed in this paper, which relate it rather to the genus Nocardia. The amidase test (Bönicke, 1960) was negative for all strains except for those of $M$. smegmatis group for which it seems to be specific.

\section{REFERENCES}

Ayers, S. H., Rupp, R. \& Johnson, W. T. (1919). A study of the alkali-forming bacteria found in milk. Bull. U.S. Dep. Agric. no. 782.

Bojalil, L. F. (1959). Estudio comparativo entre Mycobacterium marinum y Mycobacterium balnei. Rev. Latinoamer. Microbiol. 2, 169.

Bojalil, L. F. \& Cerbón, J. (1960). A comparative study of non-photochromogenic mycobacteria and Mycobacterium avium. Amer. Rev. Resp. Dis. 81, 382.

Bönicke, R. (1958). 'Atypische' Tuberkulosebakterien. Beitr. Klin. Tuberk. 121, 160.

BöNicke, R. (1960). Eine weitere Methode zur schnellen Identifizierung von Bakterienstämmen der Species Mycobacterium smegmatis (Trevisan) Lehmann und Neumann. Naturwissenschaften, 46, 562.

Frey, C. A. \& Hagan, W. A. (1931). The distribution of acid-fast bacteria in soils. J. infect. Dis. 49, 497.

Gordon, R. E. (1937). The classification of acid fast bacteria. I. J. Bact. 34, 617.

Gordon, R. E. \& HaGan, W. A. (1938). The classification of acid fast bacteria. II. $J$. Bact. 36, 39.

Gondon, R. E. \& Smith, M. M. (1953). Rapidly growing, acid fast bacteria. I. Species descriptions of Mycobacterium phlei Lehmann and Neumann and Mycobacterium smegmatis (Trevisan) Lehmann and Neumann. J. Bact. 66, 41.

Gordon, R. E. \& Smitr, M. M. (1955). Rapidly growing acid fast bacteria. II. Species' description of Mycobacterium fortuitum Cruz. J. Bact. 69, 502.

Gordon, R. E. \& MinM, J. M. (1957). A comparative study of some strains received as Nocardia. J. Bact. 73, 15.

HrLl, L. R. (1959). The Adansonian classification of the staphylococi. J. gen. Microbiol. $20,277$.

Kushner, D. S., McMrluen, S. \& Senderi, M. (1957). Atypical acid fast bacilli. II. Mycobacterium fortuitum. Bacteriologic characteristics and pathogenicity for laboratory animals. Amer. Rev. Tuberc. 76, 108.

McMillen, S. \& Kushner, D. S. (1959). Atypical acid-fast bacilli. III. An expanded schema. Amer. Rev. Resp. Dis. 80, 434. 
Parlett, R. C. \& Youmans, G. P. (1956). Antigenic relationships between mycobacteria as determined by agar diffusion precipitin techniques. Amer. Rev. Tuberc. 73, 637.

Parlett, R. C. \& Youmans, G. P. (1958). Antigenic relationships between ninety eight strains of mycobacteria using gel diffusion precipitation techniques. Amer. Rev. Tuberc. 77, 450 .

Pinner, M. (1932). Atypical acid fast organisms. Proc. Soc. exp. Biol., N.Y. 30, 214.

ShePARD, C. C. (1957). Growth characteristics in HeLa cells of the rapidly growing acidfast bacteria, Mycobacterium fortuitum, Mycobacterium phlei and Mycobacterium smegmatis. J. Bact. 73, 722.

SNEATH, P. H. A. $(1957 a)$. Some thoughts in bacterial classification. J. gen. Microbiol. $17,184$.

Sneath, P. H. A. $(1957 b)$. The application of computers to taxonomy. J. gen. Microbiol. 17, 201.

Thompson, H. M. (1932). Studies on saprophytic acid fast bacteria. Amer. Rev. Tuberc. 26, 162.

Uesaka, I. (1956). Taxonomic studies on Mycobacterium and Nocardia. I. Utilization of aminoacids on Pridham and Gottlieb's synthetic solid media. Japan. J. Tuberc. 4, 1.

Vogel, H. (1959). A metabolic study of acid fast bacteria from cold blooded animals. J. infect. Dis. 104, 28.

WAYNE, L. G. (1959). Quantitative aspects of neutral red reactions of typical and 'Atypical' mycobacteria. Amer. Rev. Tuberc. 79, 526.

WheELer, M. V. (1951). A simple procedure for the preparation of egg medium for Mycobacterium tuberculosis. J. Bact. 62, 244.

Youmans, G. P. (1946). A method for the determination of the culture cycle and the growth rate of virulent human type tubercle bacilli. J. Bact. 51, 703. 